\title{
EFFECT OF POTASSEIN SPRAY ON GROWTH, AND CHEMICAL COMPOSITION OF FURCREA FOETIDA CV. "MEDIOPICTA" L. PLANTS
}

\author{
YOUSSEF, HANAN M. A. AND HANAN E. IBRAHIM
}

Ornamental Plants Research and Landscape Gardening Department, Horticulture Research Institute, $A R C$, Giza

- (Manuscript received 27 March 2010)

\section{Abstract}

\begin{abstract}
Cacetus and succulents plants are one of the most important sources of many medical compounds, pigments and coir so they have wide range of uses in landscape of gardens. The experimental trials presented in this paper was conducted throughout two successive seasons (2008 and 2009) at the nursery of Orman Botanical garden, Giza, aiming to find out the response of two types of potassein $N(K-N)$ and potassein $P(K-P)$ for producing plants of high quality. Potassein treatments, were applied on $1^{\text {st }}$ March as a foliar spray for three times at monthly intervals at three levels $(0.00,3.00,6.00 \mathrm{ml} / \mathrm{L})$ and combination of both. Results indicated that plant height, stem diameter, number of leaves/plant, leaf area, fresh and dry weights of leaves, root length, fresh and dry weights of roots as well as chlorophyll a and $b$, carotenoids contents and N, P and $\mathrm{K}$ percentages were significantly increased in response to the various treatments used in the current study comparing with that gained from untreated plants (control).

From, the results it could be recommended that spraying the foliage of Furcrea foetida with ( $6 \mathrm{ml} / \mathrm{L}, \mathrm{K}-\mathrm{N}$ plus $6 \mathrm{ml} / \mathrm{L} \mathrm{K}-\mathrm{P}$ ), three once every month during the growing season was the best treatments in producing highest quality of growth.

Keywords: Furcrea foetida, potassein N (K-N), potassein P (KP), chemical composition.
\end{abstract}

\section{INTRODUCTION}

Furcrea foetida (Agave foetida Linn). Family Amaryllidaceae (Agavaceae) is Mauritius green Aloe, nearly trunk less Ivs. to $8 \mathrm{ft}$.long, 8 in wide, with few, distant curved in prickles $1 / 8$ in long or more, cultivated widely in the Tropics and commercially in Mauritius and St. Helena for its fiber cv. Mediopicta. It is used as a pot plant for exhibition, terrace garden , as well as display of verandah and sunny building faces,(Bailey,1976). Propagation of furcrea usually needs three years to get flowering plants from bulbles (seeds is usually rare).So in order to keep the quality and colour of the plant, it is preferable to use bulbles in propagation. As a rule ,furcreas bear fruit not more than once, and then die without producing suckers. However, they produce while in flower an immense number of bulbles, which may be used for propagation. It is impossible to say at what size or age the plants will bloom. On the other hand, plants from bulbles have been known to flower at three years. So 
increasing the bulbles production on the mother plant is considered the main target from the commercial point of view .Foliar fertilization with macro and micronutrients leads usually to considerable growth and development responses. This is manly due to the face that foliar nutrients application easily overcomes limiting soil physiochemical conditions for root nutrient uptake and because nutrients are directly applied to foliage at times when demand is particularly high and rapid responses may be desired (Alexander, 1987). Potassium is very effectuation macro element on growth, development, flowering and yield of different plants, it is a well known factor affecting many function of plants as stomatal movement, flowering and yield of different plants. Potassein $\mathrm{N}$ and potassein $\mathrm{P}$ had a great effect for regulating photosynthesis, respiratory rates and activating many enzymes involved in plant growth, it also enhances translocation of sugars and carbohydrates through plant organs, increases proteins synthesis and different metabolic processes as well as reducing respiration hence energy losses (Csizinskey, 1999).

Potassium is a foliar fertilizer is available in two forms:- one fortified with nitrogen (Potassein- $\mathrm{N}$ ) and the other with phosphorus (Potassein-P).Many investigators as Ismail et al., (2002) showed a significant stimulation on growth, root sugars and yield of sugar bear plants fertilized with either two forms of Potassein. Likewise, Mohamed and Naguib (2002) on fenugreek indicated the same observationș (fresh and dry weights of herb, chlorophyll pigment,carbohydrates and minerals content in the leaves were significantly improved as a result of spraying plants with K-P or K-N potessein at the rates of 3 or 6 L/fed. Shahin et al., (2007) noticed that fertilizer Hibiscus rosa-sinensis $\mathrm{L}$. with potassein $\mathrm{P}(\mathrm{K}-\mathrm{P}, \mathrm{K}-\mathrm{N})$, significantly increased chlorophyll a , b, cartenoids, N, P and K., Ibrahim (2009 ) on Euphorbia splendes found that potassein $(\mathrm{K}-\mathrm{P}, \mathrm{K}-\mathrm{N})$ as a foliar spray significantly increased growth and flowering of plant, chlorophyll $a, b$, cartenoids , N, P and K .

The objective of the study was to investigate the effect of potassein(K-P, K-N) spray on vegetative growth and chemical composition of Furcrea foetida $C V$. "Mediopicta" L plants.

\section{MATERIALS AND METHODS}

The experimental trial was consummated throughout two successive seasons (2008and 2009) at the nursery of Orman Botanical Garden , Giza. It was intended to find out the individual and combined effect of two types of potassein as a foliar spray on growth and chemical composition of Furcrea foetida cv. "Mediopicta" L. 


\section{Plant materials}

Seedlings of Furcrea foetida transplants with initial height of $18-20 \mathrm{~cm}$ and carries 3-4 leaves were planted on $1^{\text {st }}$ March in both seasons, individually in plastic pots of $20 \mathrm{~cm}$ diameter filled with about $2.0 \mathrm{Kg}$ of a mixture of sand, loam and peatmoss $(2: 1: 1, \mathrm{v}: \mathrm{v}: \mathrm{v})$. Therefore, the experimental trial was intended to produce vigorus, growth of Furcrea foetida plant by using either potassein (K-N and K-P) treatments which in turn increase bulbles yield and quality .

The seedlings were kept to grow under the condition of sunny area at the nursery. After one month from planting the plants were sprayed three times at one month interval till run off the solution with either potassein "K-N" (contains 30\% $\mathrm{K}_{2} \mathrm{O}$ and $8 \% \mathrm{~N}$ ) or potassein "K-P" (contains $30 \% \mathrm{~K}_{2} \mathrm{O}$ and $10 \% \mathrm{P}_{2} \mathrm{O}_{5}$ ) at three levels of ( 3.00 or $6.00 \mathrm{ml} / \mathrm{L}$ ), besides combinations of both (K-N and K-P) at also three different levels( 3.00 or $6.00 \mathrm{ml} / \mathrm{L}$ for either $\mathrm{K}-\mathrm{N}$ or K-P).

Physical properties of the used soil were analyzed according to A.O.A.C. (1985). Meanwhile, chemical properties of the used soil were analyzed according to Jackson (1985) shown in Table (a)

Table a. Physical and chemical properties of the used mixture in the two seasons.

\begin{tabular}{|c|c|c|c|c|c|c|c|c|c|c|c|c|}
\hline \multirow[b]{2}{*}{ Season } & \multicolumn{6}{|c|}{ Particles size distribution (\%) } & \multirow{2}{*}{$\begin{array}{c}\text { E.C. } \\
(\mathrm{dS} / \mathrm{m})\end{array}$} & \multirow{2}{*}{$\mathrm{pH}$} & \multicolumn{4}{|c|}{ Cations (meq/L) } \\
\hline & $\begin{array}{c}\text { Coarse } \\
\text { sand }\end{array}$ & $\begin{array}{l}\text { Fine } \\
\text { sand }\end{array}$ & Silt & Clay & $\begin{array}{l}\text { Organic } \\
\text { matter }\end{array}$ & $\mathrm{CaCO}_{3}-2-3$ & & & $\mathrm{Ca}++$ & $\mathrm{Mg}++$ & $\mathrm{Na}+$ & K+ \\
\hline 2008 & 15.2 & 25.5 & 18.4 & 36.4 & 1.70 & 2.80 & 2.99 & 7.58 & 7.55 & 2.34 & 10.90 & 0.75 \\
\hline \multirow[t]{3}{*}{2009} & 15.3 & 24.7 & 17.8 & 38.0 & 1.50 & 2.70 & 2.78 & 7.50 & 10.33 & 1.56 & 8.67 & 0.75 \\
\hline & \multicolumn{4}{|c|}{ Anions (meq/L) } & \multicolumn{8}{|c|}{ Macro-and micro-elements (ppm) } \\
\hline & $\mathrm{HCO}_{3}^{-}$ & $\mathrm{Cl}^{-}$ & so. & $24^{-}$ & $\mathrm{N}$ & $\mathrm{P}$ & K & $\mathrm{Fe}$ & $\mathrm{Zn}$ & Mn & & $\mathrm{Cu}$ \\
\hline 2008 & 3.94 & 8.64 & 8.9 & 96 & 164.20 & 17.01 & 370.50 & 12.00 & 3.70 & 7.62 & & 8.76 \\
\hline 2009 & 4.08 & 7.96 & 9.2 & 27 & 173.16 & 15.78 & 361.76 & 15.80 & 4.36 & 8.03 & 03 & 8.80 \\
\hline
\end{tabular}

Besides a combination treatment between $3 \mathrm{ml} / \mathrm{L}$. potassein $\mathrm{N}(\mathrm{K}-\mathrm{N})$ and $3 \mathrm{ml} / \mathrm{L}$ potassein $\mathrm{P}(\mathrm{K}-\mathrm{P})$ was applied to lump the benefits of both $\mathrm{N}$ and $\mathrm{P}$.

Control plants were sprayed in the same times with a tap water, however all plants under various treatments were irrigated once every 5 days with $200 \mathrm{ml}$ of water/pot(20 cm diameter) plant. 
The following nine treatments were carried out as a foliar spray

- Control.(untreated plants)

- Potassein $\mathrm{N} 3 \mathrm{ml} / \mathrm{L}(\mathrm{K}-\mathrm{N})$.

- Potassein $\mathrm{N} 6 \mathrm{ml} / \mathrm{L}(\mathrm{K}-\mathrm{N})$.

- Potassein $\mathrm{P} 3 \mathrm{ml} / \mathrm{L}(\mathrm{K}-\mathrm{P})$.

- Potassein $P 6 \mathrm{ml} / \mathrm{L}(\mathrm{K}-\mathrm{P})$.

$-K-N$ 3ml/L + K-P 3ml/L.

$-\mathrm{K}-\mathrm{N} 3 \mathrm{ml} / \mathrm{L}+\mathrm{K}-\mathrm{P} 6 \mathrm{ml} / \mathrm{L}$.

$-\mathrm{K}-\mathrm{N} 6 \mathrm{ml} / \mathrm{L}+\mathrm{K}-\mathrm{P} 3 \mathrm{ml} / \mathrm{L}$.

$-K-N 6 \mathrm{ml} / \mathrm{L}+\mathrm{K}-\mathrm{P} 6 \mathrm{ml} / \mathrm{L}$.

At the end of every season( $1^{\text {st }}$ of October), the following data were recorded: plant height $(\mathrm{cm})$, stem diameter $(\mathrm{mm})$, above $5 \mathrm{~cm}$. from the ground surface, number of leaves/plant, leaf area $\left(\mathrm{cm}^{2}\right)$ (the fifth leaves) by CL-203 AREA METER, CID, I were recorded for three randomly selected plants in each treatment .,root length $(\mathrm{cm})$ and fresh and dry weights of leaves, and roots $(\mathrm{g})$.

The chemical analysis of fresh leaves was conducted to determine their contents of chlorophyll $(\mathrm{a}, \mathrm{b})$ and total carotenoides $\mathrm{mg} / \mathrm{gm}$ F.W., using the method described by Moran (1982), then total chlorophylls content was calculated. The total carbohydrates content in dry leaves was also determined using method recommended * by Moran (1982), intended by Herbert et al., (1971) while the phosphorus colorimetrically by cottenie et al., (1982) and potassium using flame photometer (Jackson, 1973) all of them as $\mathrm{mg} / \mathrm{g}$ D.W. were measured, the content of nitrogen using micro-kjeldale method described by Jackson (1973).

The layout of the experiment in the two seasons was a complete randomized design (Das and Giri,1986) with 3 replicates as each replicates contained 5 plants. At the end of each seasons $1^{\text {st }}$ of October data were then tabulated and subjected to analysis of variance according to MSTAT-C (1990) Computer statistical analysis program, while Duncan's Multiple Range Test (1955) was used to explore the significance between the means of various treatments.

\section{RESULTS AND DISCUSSION}

\section{- Effect of potassein (K-N or K-P) on vegetative growth and roots parameter of Furcrea foetida, L.}

Data of growth parameters presented in Table (1) indicate that the plant height and stem diameter were significantly increased by using potassein $(\mathrm{N}$ or $\mathrm{P})$ at the rate of 3 or $6 \mathrm{ml} / \mathrm{L}$ or the combination of both at (K-N6 +K-P6) compared to control and other treatments. 
Table 1. Effect of Potassein ( $\mathrm{N}$ or $\mathrm{P}$ ) as a foliar spray on plant height and stem diameter of Furcrea foetida in the two seasons (2008and 2009).

\begin{tabular}{|l|c|c|c|c|}
\hline \multirow{2}{*}{ Treatments } & \multicolumn{2}{|c|}{ Plant height (cm) } & \multicolumn{2}{c|}{ Stem diameter (mm.) } \\
\cline { 2 - 5 } & First season & Second season & First season & Second season \\
\hline Control & $26.1 \mathrm{D}$ & $31.56 \mathrm{D}$ & $1.36 \mathrm{D}$ & $1.60 \mathrm{C}$ \\
\hline K-P $3 \mathrm{ml} / \mathrm{L}$ & $34.74 \mathrm{~B}$ & $37.56 \mathrm{~B}$ & $1.8 \mathrm{CD}$ & $2.81 \mathrm{AB}$ \\
\hline K-P $6 \mathrm{ml} / \mathrm{L}$ & $32.64 \mathrm{C}$ & $36.56 \mathrm{~B}$ & $2.16 \mathrm{C}$ & $2.86 \mathrm{AB}$ \\
\hline K-N 3ml/L & $32.76 \mathrm{C}$ & $37.4 \mathrm{~B}$ & $2.30 \mathrm{BC}$ & $2.76 \mathrm{~B}$ \\
\hline K-N $6 \mathrm{ml} / \mathrm{L}$ & $31 \mathrm{C}$ & $34.66 \mathrm{C}$ & $2.10 \mathrm{C}$ & $2.53 \mathrm{~B}$ \\
\hline K-P3ml/L+K-N 3ml/L & $37.64 \mathrm{~A}$ & $39.46 \mathrm{~A}$ & $2.23 \mathrm{BC}$ & $3.0 \mathrm{~A}$ \\
\hline K-P3ml/L+ K-P 6ml/L & $38.4 \mathrm{~A}$ & $39.50 \mathrm{~A}$ & $2.7 \mathrm{AB}$ & $3.0 \mathrm{~A}$ \\
\hline K-P6ml/L+K-N 3ml/L & $37.64 \mathrm{~A}$ & $39.93 \mathrm{~A}$ & $2.96 \mathrm{~A}$ & $3.1 \mathrm{~A}$ \\
\hline K-P6ml/L+ K-P 6ml/L & $39.44 \mathrm{~A}$ & $41.06 \mathrm{~A}$ & $3.06 \mathrm{~A}$ & $3.03 \mathrm{~A}$ \\
\hline
\end{tabular}

Means within column having the same letters are not significantly different according to Duncan's multiple range test (DMRT)

Meanwhile, data recorded in Tables (2 \&3) show that spraying potassein $\mathrm{N}$ or $\mathrm{P}$ or $\mathrm{N}+\mathrm{P}$ at doses $3 \& 6 \mathrm{ml} / \mathrm{L}$ significantly increased number of leaves/plant and leaf area. Whereas, praying potassein at the doses of K-N6+K-P3 or K-N6+K-P6 significantly increased fresh and dry weights of leaves/plant compared with control means or either treatments used of the two seasons.

Table 2. Effect of Potassein( $N$ or $P$ ) as a foliar spray on number of leaves / plant and leaf area of Furcrea foetida in the two seasons(2008and 2009).

\begin{tabular}{|l|c|c|c|c|}
\hline \multirow{2}{*}{ Treatments } & \multicolumn{2}{|c|}{ Number of leaves/ plant } & \multicolumn{2}{c|}{ Leaf area $\left(\mathrm{cm}^{2}\right)$} \\
\cline { 2 - 5 } & First season & Second season & First season & Second season \\
\hline Control & $5.33 \mathrm{E}$ & $7.00 \mathrm{E}$ & $50.74 \mathrm{~F}$ & $73.69 \mathrm{G}$ \\
\hline K-P 3ml/L & $7.66 \mathrm{D}$ & $10.66 \mathrm{BC}$ & $88.19 \mathrm{DE}$ & $108.98 \mathrm{CD}$ \\
\hline K-P $6 \mathrm{ml} / \mathrm{L}$ & $8.33 \mathrm{CD}$ & $10.0 \mathrm{CD}$ & $97.50 \mathrm{DE}$ & $108.47 \mathrm{CD}$ \\
\hline K-N 3ml/L & $7.66 \mathrm{D}$ & $9.00 \mathrm{D}$ & $84.11 \mathrm{E}$ & $102 . .21 \mathrm{FF}$ \\
\hline K-N $6 \mathrm{ml} / \mathrm{L}$ & $8.33 \mathrm{CD}$ & $9.66 \mathrm{CD}$ & $79.72 \mathrm{E}$ & $98.06 \mathrm{~F}$ \\
\hline K-P3ml/L+K-N 3ml/L & $9.00 \mathrm{C}$ & $11.66 \mathrm{AB}$ & $104.02 \mathrm{BC}$ & $117.12 \mathrm{BC}$ \\
\hline K-P3ml/L+K-P 6ml/L & $9.33 \mathrm{BC}$ & $12.33 \mathrm{~A}$ & $97.50 \mathrm{CD}$ & $115.89 \mathrm{BC}$ \\
\hline K-P6ml/L+K-N 3ml/L & $10.33 \mathrm{~A}$ & $12.00 \mathrm{AB}$ & $111.91 \mathrm{AB}$ & $124.82 \mathrm{~B}$ \\
\hline K-P6ml/L+K-P $6 \mathrm{ml} / \mathrm{L}$ & $10.66 \mathrm{~A}$ & $12.00 \mathrm{AB}$ & $118.31 \mathrm{~A}$ & $134.65 \mathrm{~A}$ \\
\hline
\end{tabular}

Means within column having the same letters are not significantly different according to Duncan's multiple range test (DMRT) 
Table 3. Effect of Potassein( $\mathrm{N}$ or $\mathrm{P}$ ) as a foliar spray on fresh and dry weights of leaves / plant of Furcrea foetida in the two seasons(2008and 2009).

\begin{tabular}{|l|c|c|c|c|}
\hline \multirow{2}{*}{ Treatments } & \multicolumn{2}{|c|}{ Number of leaves / plant } & \multicolumn{2}{c|}{ Leaf area $\left(\mathrm{cm}^{2}\right)$} \\
\cline { 2 - 5 } & First season & Second season & First season & Second season \\
\hline Control & $24.22 \mathrm{~F}$ & $28.51 \mathrm{G}$ & $5.01 \mathrm{D}$ & $8.21 \mathrm{C}$ \\
\hline K-P $3 \mathrm{ml} / \mathrm{L}$ & $32.22 \mathrm{E}$ & $41.92 \mathrm{DEF}$ & $6.62 \mathrm{C}$ & $10.27 \mathrm{~B}$ \\
\hline K-P $6 \mathrm{ml} / \mathrm{L}$ & $37.79 \mathrm{D}$ & $46.47 \mathrm{BC}$ & $7.18 \mathrm{BC}$ & $12.69 \mathrm{~A}$ \\
\hline K-N 3ml/L & $31.97 \mathrm{E}$ & $36.72 \mathrm{~F}$ & $6.55 \mathrm{C}$ & $9.74 \mathrm{~B}$ \\
\hline K-N $6 \mathrm{ml} / \mathrm{L}$ & $34.51 \mathrm{E}$ & $39.54 \mathrm{EF}$ & $6.61 \mathrm{C}$ & $9.61 \mathrm{BC}$ \\
\hline K-P3ml/L+K-N 3ml/L & $38.65 \mathrm{CD}$ & $49.92 \mathrm{BCD}$ & $7.79 \mathrm{~B}$ & $13.33 \mathrm{~A}$ \\
\hline K-P3ml/L+ K-P $6 \mathrm{ml} / \mathrm{L}$ & $41.64 \mathrm{~A}$ & $53.74 \mathrm{AB}$ & $9.15 \mathrm{~A}$ & $13.66 \mathrm{~A}$ \\
\hline K-P6ml/L+K-N 3ml/L & $41.19 \mathrm{AB}$ & $57.67 \mathrm{AB}$ & $8.92 \mathrm{~A}$ & $13.37 \mathrm{~A}$ \\
\hline K-P6ml/L+ K-P $6 \mathrm{ml} / \mathrm{L}$ & $46.14 \mathrm{~A}$ & $58.94 \mathrm{~A}$ & $9.51 \mathrm{~A}$ & $14.19 \mathrm{~A}$ \\
\hline
\end{tabular}

Means within column having the same letters are not significantly different according to Duncan's multiple range test (DMRT)

Data scored in Table (4) show clearly that root parameters of Furcrea foetida $c v$. mediopicta $L$ was influenced by using potassein treatment in fertilization . In this connection, applying potassein at different levels (K-N6 +K-P3 or K-N6 + K-P6) revealed highly significant increment on root length and its fresh and dry weights in both seasons.

Table 4. Effect of Potassein( $N$ or $P$ ) as a foliar spray on root length and fresh and dry weights of roots of Furcrea foetida in the two seasons(2008and 2009).

\begin{tabular}{|l|c|c|c|c|c|c|}
\hline \multirow{2}{*}{ Treatments } & \multicolumn{2}{|c|}{ Root Length (cm) } & \multicolumn{2}{c|}{$\begin{array}{c}\text { Fresh weight of Root } \\
\text { /plant (gm.) }\end{array}$} & \multicolumn{2}{c|}{$\begin{array}{l}\text { Dry weight of Root/ } \\
\text { plant (gm.) }\end{array}$} \\
\cline { 2 - 8 } & $\begin{array}{c}\text { First } \\
\text { season }\end{array}$ & $\begin{array}{c}\text { Second } \\
\text { season }\end{array}$ & $\begin{array}{c}\text { First } \\
\text { season }\end{array}$ & $\begin{array}{c}\text { Second } \\
\text { season }\end{array}$ & $\begin{array}{c}\text { First } \\
\text { season }\end{array}$ & $\begin{array}{c}\text { Second } \\
\text { season }\end{array}$ \\
\hline Control & $9.90 \mathrm{G}$ & $11.46 \mathrm{E}$ & $3.22 \mathrm{~F}$ & $3.11 \mathrm{C}$ & $1.88 \mathrm{~F}$ & $1.82 \mathrm{D}$ \\
\hline K-P $3 \mathrm{ml} / \mathrm{L}$ & $14.54 \mathrm{CD}$ & $16.10 \mathrm{BC}$ & $3.62 \mathrm{EF}$ & $4.22 \mathrm{~B}$ & $2.18 \mathrm{DE}$ & $2.18 \mathrm{BCD}$ \\
\hline K-P $6 \mathrm{ml} / \mathrm{L}$ & $15.54 \mathrm{BC}$ & $16.83 \mathrm{~B}$ & $4.22 \mathrm{BCD}$ & $4.38 \mathrm{~B}$ & $2.20 \mathrm{DE}$ & $2.14 \mathrm{CD}$ \\
\hline K-N 3ml/L & $12.34 \mathrm{~F}$ & $13.73 \mathrm{D}$ & $3.81 \mathrm{DEF}$ & $4.09 \mathrm{~B}$ & $2.19 \mathrm{DE}$ & $2.09 \mathrm{CD}$ \\
\hline K-N $6 \mathrm{ml} / \mathrm{L}$ & $13.60 \mathrm{EF}$ & $15.23 \mathrm{C}$ & $3.92 \mathrm{EF}$ & $4.09 \mathrm{~B}$ & $2.41 \mathrm{CD}$ & $2.08 \mathrm{CD}$ \\
\hline K-P3ml/L+K-N 3ml/L & $14.56 \mathrm{CD}$ & $17.16 \mathrm{~B}$ & $4.43 \mathrm{BC}$ & $5.55 \mathrm{AB}$ & $2.97 \mathrm{AB}$ & $2.47 \mathrm{BC}$ \\
\hline K-P3ml/L+K-P $6 \mathrm{ml} / \mathrm{L}$ & $15.70 \mathrm{BC}$ & $18.36 \mathrm{~A}$ & $4.85 \mathrm{AB}$ & $5.08 \mathrm{~B}$ & $2.78 \mathrm{BC}$ & $2.53 \mathrm{~B}$ \\
\hline K-P6ml/L+K-N 3ml/L & $16.80 \mathrm{AB}$ & $19.26 \mathrm{~A}$ & $4.99 \mathrm{AB}$ & $5.53 \mathrm{AB}$ & $3.03 \mathrm{AB}$ & $2.55 \mathrm{~B}$ \\
\hline K-P6ml/L+K-P $6 \mathrm{ml} / \mathrm{L}$ & $18.03 \mathrm{~A}$ & $19.43 \mathrm{~A}$ & $5.41 \mathrm{~A}$ & $5.86 \mathrm{~A}$ & $3.27 \mathrm{~A}$ & $2.94 \mathrm{~A}$ \\
\hline
\end{tabular}

Means within column having the same letters are not significantly different according to Duncan's multiple range test (DMRT) 
The increment on vegetative and root growth of Euphorbia due to potasseins application might be attributed to function of potassium on cell division and elongation, carbohydrates and protein synthesis, activating translocation of sugars and starch in plant organs, as well as its role as a Co-factor for about 60 enzymes involved in plant. Ismial et al., (2002) scored a significant stimulation on growth, root sugars and yield of sugar-beet plants fertilized with either forms of potassein. Likewise, Mohamed and Naguib (2002) on Fenugreek indicated that plant height, number of branches/plant, fresh and dry weights of herb, chlorophylls pigments, carbohydrates and minerals content in the leaves were significantly improved as a result of spraying with K-P or K-N potassein at the rates of 3 or $6 \mathrm{~L} / \mathrm{fed}$.

The effect of nutrition was mainly studied by application $\mathrm{N}, \mathrm{P}$ and $\mathrm{K}$ as main nutrients in several forms. However, the current work is an attempt to study the response of Furcrea foetida $\mathrm{CV}$. "Mediopicta" L., plant to foliar spray with two forms of potassein- $N(K-N)$, potassein- $P(K-P)$ and the combined treatment of both on growth develop, and chemical composition. Csizinskey (1999) which were reflected in taller plants bearing more leaves and branches containing more metabolites and food reserves and consequently heavier plant weight. Such improvement of potassein forms on plant growth traits was also observed by Ahmed, (2002) on Horworthia forciata. In addition to the great contribution of $\mathrm{N}$ plant materials as it is a main constituent of al proteins and nucleic acid as well as of both structural and non-structural components of plant cells, besides involving $P$ in energy transfer process and is building of phospholipids and nucleic acid.

Effect of potassein (K-N or K-P) on chemical composition of Furcrea foetida

From data averaged in Table (5), it is clear that the contents of chlorophyll $a, b$ and carotenoids (mg/g F.W.), total carbohydrates (mg/g D.W.) and the percentages of $\mathrm{N}, \mathrm{P}$ and $\mathrm{K}$ were markedly increased in the leaves of fertilized plants due to the different treatments of fertilization, with the excellence of the high rate of potassein fertilizer (K$\mathrm{N} 6+\mathrm{K}-\mathrm{P} 6 \mathrm{ml} / \mathrm{L}$ ) that gave the utmost high means in the two seasons with significant differences when compared to means of either control or other treatments.

These results come in response to the role played by $\mathrm{N}$ in chlorophylls and amino acids synthesis and $\mathrm{P}$ which contributes in regulating the opening and closing of stomata and possible membrance turgar that effect chlorophyll properties and phosphorus would activate various metabolic processes and it is involved in energy transfer process during building of phospholipids and nucleic acid Ahmed (2002).

Moreover, $\mathrm{P}$ provides plant metabolic process with phosphate bond which are necessary for building pigments and other constituents Ahmed, (2002). Several 
workers referred to the stimulatory effects of $\mathrm{K}, \mathrm{P}$ and $\mathrm{N}$ fertilization on chlorophyll and other constituents formations as Shahin et al., (2007)on Hibiscus rosa-sinensis $L$.

Finally, from the previously stated results it could be recommended to spray the foliage of Furcrea foetida $\mathrm{Cr}$." Mediopicta" L. transplants grown is $20 \mathrm{~cm}$ diameter pots thrice with a combination of $6 \mathrm{ml} / \mathrm{L}$ potassein $\mathrm{N}$ at $6 \mathrm{ml} / \mathrm{L}$ potassein $\mathrm{P}$ at one month interval to get vigour growth .

Table 5. Effect of Potassein( $\mathrm{N}$ or $\mathrm{P}$ ) as a foliar spray on chemical composition of Furcrea foetida.

\begin{tabular}{|c|c|c|c|c|c|c|c|}
\hline Treatments & $\begin{array}{c}\text { Chlorophyll } \\
\text { A } \\
\text { (mg/g } \\
\text { F.W.) }\end{array}$ & $\begin{array}{l}\text { Chlorophyll } \\
\text { B } \\
\text { (mg/g F.W.) }\end{array}$ & $\begin{array}{l}\text { Carotenoids } \\
\text { (mg/g F.W.) }\end{array}$ & $\begin{array}{c}\text { Total } \\
\text { carbohydrates } \\
\text { (mg/g.D.W) }\end{array}$ & $\begin{array}{l}\mathrm{N} \\
\%\end{array}$ & $\begin{array}{l}\mathrm{P} \\
\%\end{array}$ & $\begin{array}{l}\mathrm{K} \\
\%\end{array}$ \\
\hline Control & $3.61 \mathrm{~F}$ & $.99 \mathrm{H}$ & $1.57 \mathrm{G}$ & $5.61 \mathrm{H}$ & $0.57 \mathrm{E}$ & $0.33 \mathrm{DE}$ & $0.24 \mathrm{G}$ \\
\hline $\mathrm{K}-\mathrm{P} 3 \mathrm{ml} / \mathrm{L}$ & 4.210 & $1.39 \mathrm{E}$ & $1.73 \mathrm{E}$ & $9.47 \mathrm{G}$ & $0.68 \mathrm{D}$ & $0.17 \mathrm{E}$ & $2.41 \mathrm{E}$ \\
\hline K-P $6 \mathrm{ml} / \mathrm{L}$ & $4.87 \mathrm{C}$ & $1.47 \mathrm{C}$ & $1.79 \mathrm{D}$ & $12.09 \mathrm{~F}$ & $0.74 \mathrm{C}$ & $0.37 D E$ & $1.88 \mathrm{~F}$ \\
\hline $\mathrm{K}-\mathrm{N} 3 \mathrm{ml} / \mathrm{L}$ & 3.97E & $1.19 \mathrm{G}$ & $1.6 \mathrm{~F}$ & 15.32E & $0.66 \mathrm{D}$ & $0.37 \mathrm{DE}$ & $1.93 \mathrm{~F}$ \\
\hline $\mathrm{K}-\mathrm{N} 6 \mathrm{ml} / \mathrm{L}$ & 4.18DE & $1.37 \mathrm{~F}$ & $1.8 \mathrm{D}$ & $16.06 \mathrm{D}$ & $0.68 \mathrm{D}$ & $0.41 \mathrm{CDE}$ & $2.33 \mathrm{E}$ \\
\hline $\mathrm{K}-\mathrm{P} 3 \mathrm{ml} / \mathrm{L}+\mathrm{K}-\mathrm{N} 3 \mathrm{ml} / \mathrm{L}$ & $4.87 \mathrm{C}$ & $1.41 \mathrm{D}$ & $1.86 \mathrm{C}$ & $18.65 \mathrm{C}$ & $0.76 \mathrm{C}$ & $0.581 \mathrm{BCD}$ & $2.93 \mathrm{D}$ \\
\hline $\mathrm{K}-\mathrm{P} 3 \mathrm{ml} / \mathrm{L}+\mathrm{K}-\mathrm{P} 6 \mathrm{ml} / \mathrm{L}$ & $5.13 \mathrm{AB}$ & $1.45 \mathrm{C}$ & $1.88 \mathrm{BC}$ & $18.87 \mathrm{C}$ & $0.83 \mathrm{~B}$ & $0.66 \mathrm{AB}$ & $3.39 \mathrm{C}$ \\
\hline $\mathrm{K}-\mathrm{P} 6 \mathrm{ml} / \mathrm{L}+\mathrm{K}-\mathrm{N} 3 \mathrm{ml} / \mathrm{L}$ & $5.02 B C$ & $1.71 \mathrm{~B}$ & $1.89 \mathrm{~B}$ & $19.68 \mathrm{~B}$ & $0.95 \mathrm{~A}$ & $0.73 \mathrm{AB}$ & $3.72 \mathrm{~B}$ \\
\hline $\mathrm{K}-\mathrm{P} 6 \mathrm{ml} / \mathrm{L}+\mathrm{K}-\mathrm{P} 6 \mathrm{ml} /$ & $5.28 \mathrm{~A}$ & $1.94 \mathrm{~A}$ & $1.93 \mathrm{~A}$ & $20.85 \mathrm{~A}$ & $0.96 \mathrm{~A}$ & $0.86 \mathrm{~A}$ & 3.93A \\
\hline
\end{tabular}

Means within column having the same letters are not significantly different according to Duncan's multiple range test (DMRT)

\section{REFERENCES}

1. Alexander, A. 1987. Optimum time of foliar nutrient spray In: Alexander (ed) foliar fertilization P. 44-60 Martinus Nihaff publisher N.Y.

2. Ahmed, A. Abd. El. J. 2002. Effect of growth media and chemical fertilization on growth and chemical composition of Gasteria and Haworthia plants. Ph.D. Thesis, Hort. Dept., Fac. of Agric.,Cairo Univ.

3. A.O.A.C. 1985. Official Methods of Analysis Ed by Hornitzw. Association of Official Analytical chemists, Washington Dc, 34-47.

4. Bailey,L.H. 1976. Hortus Third.Macmillan UplishingCo,INC.,866 Third Avenue, New York, N.Y. 10022.1290 pp.

5. Csiznskey, A.A. 1999. Yield response of herbs to $\mathrm{N}$ and $\mathrm{K}$ in sand spices and medic plants. 6(4): 11-22. 
6. Cottenie, A.M., L., Verloo, G. Kiekan Velghe and R. Comerlynex. 1982. Chemical Analysis of plants and soils laboratory of Analytical and Agrochemistry State Univ Ghent-Belgium. P: 44-45.

7. Das, M.N. and N.C. Giri 1986. Design and Analysis of Experiments, $2^{\text {nd }}$ Ed,Published by Mohinder singh sejwal for Wiley, New Delhi 110002,488pp.

8. Duncan, D.B. (1955): Multiple range and multiple F-tests. Biometrices, 11:1-42.

9. Herbert, D., P.J. Philipps and R.E. Strange. 1971. Determination of total Carbohydrates methods in microbiology. 5(6): 204-244.

10. Ibrahim, Hanan. E. 2009. Effect of potassein spray on vegetative growth, flowering and chemical composition of Euphorbia splendes plants .J. Agric. Mansoura Univ., Sci. 34 (5)4883-4891.

11. Ismail, A.M., K.H.A. Abou-Shady and S.M. Alam. 2002. Response of some sugarbeet varieties to methods of K application. Egypt J. Appl. Sci, 17(2): 86-101.

12. Jackson, M.L. 1973. Soil Chemical Analysis Prentice-Hall of India Private Ltd M- 97, New Delhi, India. 498 pp.

13. Jackson, M.L. 1985. Soil Chemical Analysis prentice Hall, Inc, Unglewood.Cliffs.N.S.

14. Mohamed, S.A. and Nabila, Y. Naguib. 2002. Influence of foliar sprays with potassein $\mathrm{P}, \mathrm{N}$, ascobine and their combinations on yield and chemical constituents of fenugreek seeds. Arab Univ. J. Agric Sci, Ain Shams Univ, Cairo, 10(3): 879-891.

15. Moran, R. 1982. Formula for determination of chlorophyllous pigment extracted with N-N-dimethyl formamide. Plant physiol., 69:1376-81.

16. MSTAT, C. 1990. Microcomputer statistical program for experiment design and analysis. MSTAT / Michigan State University, Michigan, USA.

17. Shahin, S.M, Naglaa Y.L. Eliwa and Boshra, A. El-Sayed. 2007. Growth, flowering and chemical composition of Hibiscus-rosa- sinensis L. transplants as affected by foliar spray with two forms of potassein. J. Bio.I Chem. Environ Sci, 2(4): 151-165. 


$$
\begin{aligned}
& \text { تأثير الرش بالبوتاسين على النمو والثركيب الكيماوي لنبات الفوركاريا } \\
& \text { حنان محمد أحمد يوسف حنان عز الدين إيراهيم }
\end{aligned}
$$

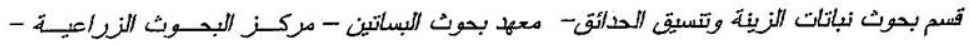

$$
\begin{aligned}
& \text { الجيزة - جدهورية مصر العربية }
\end{aligned}
$$

الثباتات الشوكية والعصارية واحده من أهم المصادر للعديد من المركبات الطببية والصبغات

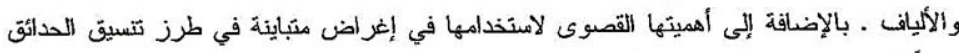

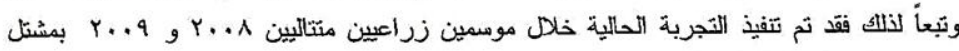

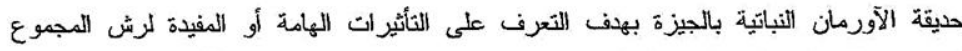

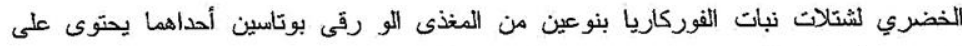

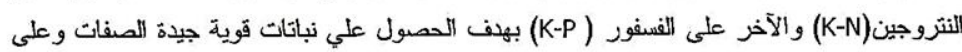

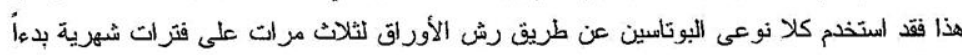

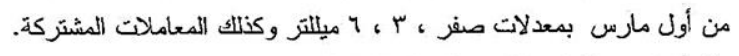

وقد أوضحت النتائج المتحصل عليها ما يلي:-

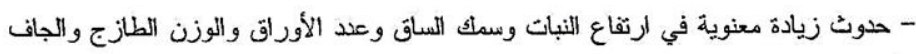

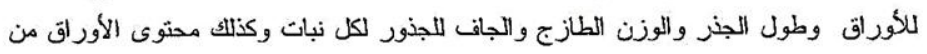

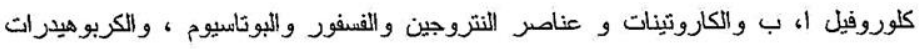

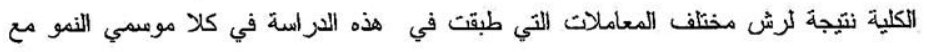

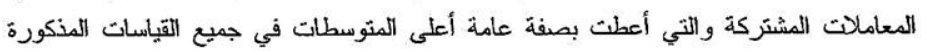
سابقا عند مقارنتها بالكنترول و المعاملات الأخرى.

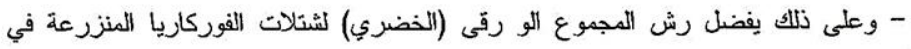

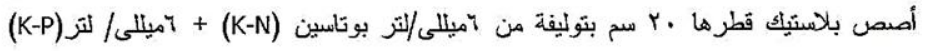
ثلاث مرات كل شهز للحصول على اعلي جودة للنمو.

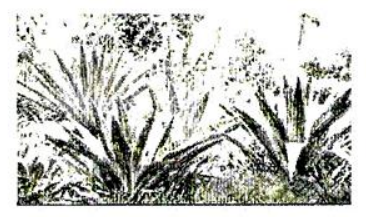

